\title{
Analysis of The Style of Learning Based on Visual, Auditorial, Kinesthetic on Students of Computer System
}

\author{
Ni Wayan Suardiati Putri ${ }^{1}$, Ni Kadek Suryati ${ }^{2}$ \\ ${ }^{1,2}$ Computer Systems Study Program, STMIK STIKOM Indonesia, Indonesia \\ ${ }^{1}$ suardiatiputri@stiki-indonesia.ac.id, ${ }^{2}$ kadeksuryati8@gmail.com
}

\begin{abstract}
(2)
Keywords:

Learning Styles;

Visual;

Auditorial;

Kinesthetic;

Student Learning Style.

ABSTRACT

This study aims to describe the results of analysis of student learning styles based on Visual, Auditorial, Kinesthetic Computer System Study Program Class of 2019. The research method used is descriptive. Descriptive research was chosen because the researcher would describe and present a complete picture of the condition or relationship by describing each variable. The sample selection is done by purposive random sampling. The instruments used in this study were visual, auditory, and kinetic learning style questionnaires. Based on the research results it is known that the students of the Computer System Study Program in 2019 have a tendency towards kinesthetic learning styles. From 124 students, it was found that $13 \%$ Visual, 35\% Auditorial, 42\% Kinesthetic, 3\% Combined Visual and Auditorial, 5\% Combined Visual and Kinesthetic, and 2\% Combined Auditorial and Kinesthetic.
\end{abstract}

Article History:

Received: 25-02-2020

Revised : 13-04-2020

Accepted: 13-04-2020

Online : 14-04-2020

\author{
(c) (1) (2) \\ This is an open access article under the CC-BY-SA license \\ Crossret \\ https://doi.org/10.31764/ijeca.v3i1.2056
}

\section{A. INTRODUCTION}

Appropriate learning styles are the key to student success in learning. The use of learning styles that are limited to only one style, especially those that are verbal or auditory, can certainly cause many differences in absorbing information. Therefore, in learning activities, students must be assisted and directed to recognize learning styles that suit themselves so that learning outcomes can be maximized (Arylien Ludji Bire, Uda Geradus, 2014). According to (Potter \& Mike, 2011) in his book entitled "Quantum learning to make learning comfortable and enjoyable" explained that learning styles are keywords to develop performance at work, at school, and in interpersonal situations. When you realize how you and others absorb and process information, you can make learning and communicating easier in your own style.

In following the learning process, each student has a different learning style between one student and another. Lecturers in teaching must pay attention to student learning styles. This is because in every teaching its effectiveness will depend very much on the way or style of student learning, besides personal characteristics and intellectual abilities. Learning styles of students can be observed from the multiple intelligences they have and each student has their own dominant intelligence. The importance of the lecturer knowing the learning styles of all his students is based on the ineffectiveness of learning in the classroom. Musrofi (Pratiwi, Joharman, \& Suyanto, 2014) said that only $30 \%$ of students succeeded in participating in class learning because they had a learning style that was in accordance with the teaching style applied by lecturers in the classroom. The rest, as many as $70 \%$ of students have difficulty in following 
learning in the classroom because they have other learning styles, which are not in accordance with the teaching styles applied in the classroom. That is, $70 \%$ of student styles are not accommodated by the teaching style of lecturers in learning. The same thing also expressed by Grinder in Siberman, (Sari, 2014) states that for every 30 students, 22 of them on average can learn effectively as long as their teacher presents learning activities that combine visual, auditory, and kinesthetic. But the rest are so fond of one form of teaching compared to the other two, so that students must strive to understand the lesson if there is no precision in presenting the lesson in the way they prefer.

De Poter \& Hernacki (Erawati \& Putri, 2019) explained in general human learning styles are divided into three big groups, namely visual learning styles, auditory learning styles and kinesthetic learning styles. Visual learning styles are learning styles by looking, observing, looking at, and the like. The strength of this learning style lies in the sense of sight. For people who have this style, the eye is the most sensitive tool for capturing every symptom or stimulus (stimulus) of learning. Auditory learning style is a learning style by listening. Individuals with this learning style, are more dominant in using the sense of hearing to carry out learning activities. Individuals are easy to learn, easy to catch stimulus or stimulation when through the sense of hearing (ear). Individuals with an auditory learning style have power in their ability to hear. Kinesthetic learning styles are learning styles by moving, working, and touching. The point is to learn by giving priority to the sense of taste and physical movements. Individuals with this learning style find it easier to grasp lessons when they move, feel, or take action. Research on learning styles is also carried out by (Wahyuni, 2017), (Wassahua, 2016), (Widayanti, 2013), and (Papilaya \& Huliselan, 2016).

The purpose of this study is to describe the results of analysis of student learning styles based on Visual, Auditorial, and Kinesthetic in the Computer Systems Study Program. So that it can be a reference for Lecturers in choosing appropriate learning styles to be applied to students.

\section{B. METHODS}

The research method used is descriptive. Descriptive research was chosen because the researcher would describe and present a complete picture of the condition or relationship by describing each variable. The sample selection is done by purposive random sampling, namely by choosing subjects that fit the criteria after learning the type of learning style is known. Data collection uses a learning style questionnaire. Questionnaire contains a number of written questions that are used to obtain information from research subjects related to some characteristics of learning styles. The questionnaire instrument was not tested but was only validated by linguists to avoid ambiguity or multiple interpretations of the questions in it. Judging from how to answer it, the questionnaire used was included in a closed questionnaire, because the research subjects were provided the answer. Judging from the answer, the questionnaire used in this study was a direct questionnaire because the research subjects answered directly about themselves. While the techniques used in data collection in this study were questionnaire techniques. Questionnaire data obtained from each respondent will be recapitulated based on each learning style. The following are some steps in the analysis of the data: (1) There are several questions in the questionnaire instrument that will be filled by responses. There are 3 question groups namely Visual learning style group, Auditorial learning style group, and kinesthetic learning style group. Each question has an answer choice which is: "often" is given a score of 2 , "sometimes" is given a score of 1 , and "rarely" is given a score of 0 . (2) From each group of learning style questions, the score is added up so that at each each group learning style questions will produce a certain value. (3) Drawing a conclusion about the tendency of the learning style by comparing the three values of each group of questions filled by the subject. Conclusions are based on: a) If there is a highest score in a group of learning style questions, then it is concluded that the subject tends to be dominant in the learning style; b) If there are two highest scores that are the same from the two groups of learning style questions, then the subject belongs to the "Combination of the two Learning Styles". c) If there are two highest scores from two groups of learning style questions that are 1 point at odds, then the 
subject belongs to the "Combined Learning Styles". (Sari, 2014) After that, a recapitulation will be made in the form of: a) percentage of learning styles from the Computer System Study Program class of 2019; b) percentage of overall learning styles of students in class 2019.

\section{RESULT AND DISCUSSION}

After completing the learning style questionnaire instrument by 124 research subjects from 2019 Computer Systems Study Program students, an analysis / calculation of the scores for each research subject was conducted. In drawing conclusions, a subject tends to a learning style, this study determines 6 groups of learning style trends, namely: 1. Visual, 2. Auditorial, 3. Kinesthetic, 4. Combination between Visual and Auditorial, 5. Combination between Visual and Kinesthetic, 6 Combination between Auditorial and Kinesthetic.

\section{Learning Style of Computer Systems Study Program Class of 2019}

The results of the analysis of learning styles towards 2019 Students in the Computer Systems Study Program produced 13\% Visual, 35\% Auditorial, 42\% Kinesthetic, 3\% Combination between Visual and Auditorial, 5\% Combination between Visual and Kinesthetic, and 2\% Combination between Auditorial and Kinesthetic. Thus, the dominance of the Student Learning Style of the Computer System Study Program in 2019 is the Kinesthetic learning style. Complete data Learning styles are presented in Table 1 and Figure 1.

Table 1. Learning styles of class of students of Computer Systems Study Program class of 2019

\begin{tabular}{llrr}
\hline No & Learning style & Frequency & Percentage \\
\hline 1. & Visual & 16 & $13 \%$ \\
\hline 2. & Auditorial & 43 & $35 \%$ \\
\hline 3. & Kinesthetic & 52 & $42 \%$ \\
\hline 4. & Combination between Visual and Auditorial & 4 & $3 \%$ \\
\hline 5. & Combination between Visual and Kinesthetic & 6 & $5 \%$ \\
\hline 6. & Combination between Auditorial and Kinesthetic & 3 & $2 \%$ \\
\hline & Total & 124 & $100 \%$ \\
\hline
\end{tabular}

$\begin{array}{ll}\text { - Visual } & \text { Auditorial } \\ \text { - Kinesthetic } & =\text { Combination between Visual and Auditorial } \\ \text { - Combination between Visual and Kinesthetic } & \quad \text { Combination between Auditorial and Kinesthetic }\end{array}$

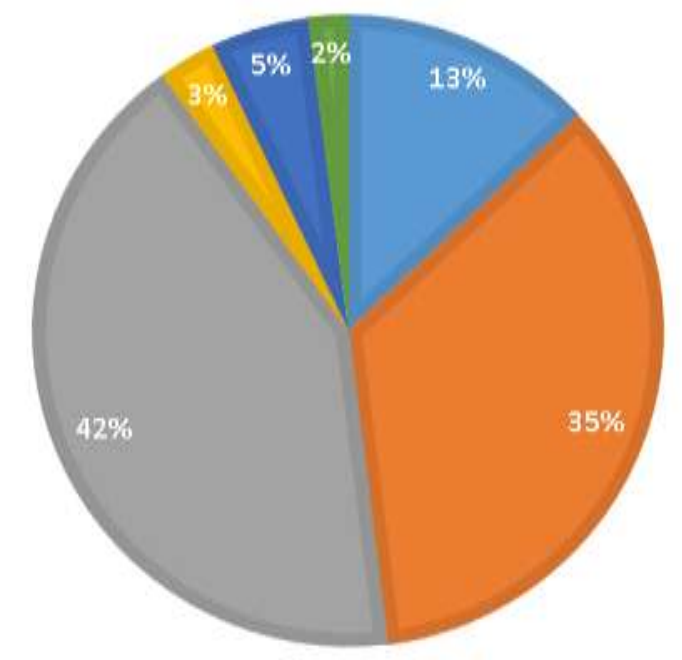

Figure 1. Diagram of the percentage of learning styles of students of the Computer Systems Study Program 2019 
From Table 1 it can be seen that most students (42\%) have kinesthetic learning styles. Based on the results of the analysis of the visual, auditory and kinesthetic learning style questionnaire, it is known the tendency of student learning styles when viewed from high category scores. The results show that 16 students have a tendency for visual learning styles, 43 students have a tendency of auditory learning styles, 52 students have a tendency of kinesthetic learning styles, 4 students have a tendency of learning styles of visual learning styles and auditory learning styles, 6 students have a tendency of learning styles of learning styles visual and kinesthetic learning styles, 3 students have the tendency of auditory learning style learning styles and kinesthetic learning styles. If illustrated with a diagram, the percentage of students who have a tendency for visual, auditory, kinesthetic, or mixed learning styles is shown in Figure 1.

As the results of this study, 2019 Computer Systems Study Program students are more likely to have a kinesthetic learning style. In line with the opinion of Bobbi Deporter and Singer Nourie in (Indra Setiawan \& Waspodo, 2015) "that in reality, students have all three learning styles, only usually tend to one particular learning style". (Sari, 2014) also revealed Learning for Kinesthetic Students, namely Movement, coordination, rhythm, emotional responses, and physical comfort were very prominent in highly kinesthetic students. In accordance with what was expressed in Deporter et al in (Sari, 2014) that some characteristics of a kinesthetic person include: a) often touching people, standing close together, and moving when interacting with others; b) learn by doing; b) designate writing while reading; c) remember while walking and looking. Therefore, the kinesthetic learning style is in accordance with the Computer Systems Study Program considering that lecture activities not only provide theory but also practice. Besides the evaluation of learning conducted at the Computer System Study Program also uses a demo project, where students work on a project which subsequently conducts assistance and demonstrations to supporting lecturers. This makes students not only have knowledge but also skills especially in the field of Computer Systems.

\section{CONCLUSION AND SUGGESTIONS}

Based on the research objectives and results as well as the discussion is concluded as follows analysis of the learning styles of the students Forces in 2019 in Prodi Computer System generates as much as $13 \%$ visual, $35 \%$ auditory, $42 \%$ Kinesthetic, 3\% combination between Visual and auditory, 5\% combination between Visual and kinesthetic, and 2\% combination between auditory and kinesthetic. The results of this study indicate that students are more likely to have a Kinesthetic learning style. The suggestion is for lecturers to be more sensitive and understand the learning styles of each student so that they can assist them in the learning process.

\section{ACKNOWLEDGEMENT}

Thank you to the head of the Computer Systems study program for facilitating the author in conducting research. Besides that, the LPPM STMIK STIKOM Indonesia also assisted the writer in writing scientific articles.

\section{REFERENCES}

Arylien Ludji Bire, Uda Geradus, dan J. B. (2014). Pengaruh Gaya Belajar Visual, Auditorial, Dan Kinestetik Terhadap Prestasi Belajar Siswa. Pengaruh Gaya Belajar Visual, Auditorial, Dan Kinestetik Terhadap Prestasi Belajar Siswa, 44(2). https://doi.org/10.21831/jk.v44i2.5307

Erawati, N. K., \& Putri, N. W. S. (2019). Analisis Kemampuan Komunikasi Matematis Mahasiswa dalam Penyelesaian masalah ditinjau dari Gaya Belajar. Prosiding Senama PGRI, 1, 50-59. https://doi.org/10.5281/zenodo.3376423

Indra Setiawan, A., \& Waspodo, M. (2015). Hubungan Antara Gaya Belajar Dan Konsep Diri Dengan Hasil Belajar Matematika (Studi Korelasional pada Siswa Kelas VI SDN Mulyasari Kecamatan Gunungsindur Kabupaten Bogor). Jurnal Teknologi Pendidikan, 4(2), 30-42. https://doi.org/10.32832/tek.pend.v4i2.481

Papilaya, J. O., \& Huliselan, N. (2016). Identifikasi Gaya Belajar Mahasiswa. Jurnal Psikologi Undip, $15(1), 56$. https://doi.org/10.14710/jpu.15.1.56-63 
Potter, B. de, \& Mike, H. (2011). Quantum Learning nyaman dan menyenangkan. Bandung: Kaifa.

Pratiwi, D., Joharman, \& Suyanto, I. (2014). Gaya Belajar Dominan Pada Siswa Berprestasi Dalam Kegiatan Pembelajaran di SD Negeri 2 Gombong Tahun Ajaran 2013/2014. Kalam Cendika PGSD Kebumen, 11(43), 25-35. Retrieved from http://journals.modares.ac.ir/article-7-5570-fa.html

Sari, A. K. (2014). Analisis Karakteristik Gaya Belajar Vak ( Visual , Auditorial , Kinestetik ) Mahasiswa Pendidikan. Jurnal Ilmiah Edutic, 1(1), 1-12.

Wahyuni, Y. (2017). Identifikasi Gaya Belajar (Visual, Auditorial, Kinestetik) Mahasiswa Pendidikan Matematika Universitas Bung Hatta. Jurnal Penelitian Dan Pembelajaran Matematika, 10(2), 128-132. https://doi.org/10.30870/jppm.v10i2.2037

Wassahua, S. (2016). Analisis Gaya Belajar Siswa Terhadap Hasil Belajar Matematika Pada Materi Himpunan Siswa Kelas Vii Smp Negeri Karang Jaya Kecamatan Namlea Kabupaten Buru. Jurnal Matematika Dan Pembelajarannya, 105-126. https://doi.org/http://dx.doi.org/10.33477/mp.v4i1.310

Widayanti, F. D. (2013). Pentingnya Mengetahui Gaya Belajar Siswa Dalam Kegiatan Pembelajaran Di Kelas. Erudio Journal of Educational Innovation, 2(1). https://doi.org/10.18551/erudio.2-1.2 